
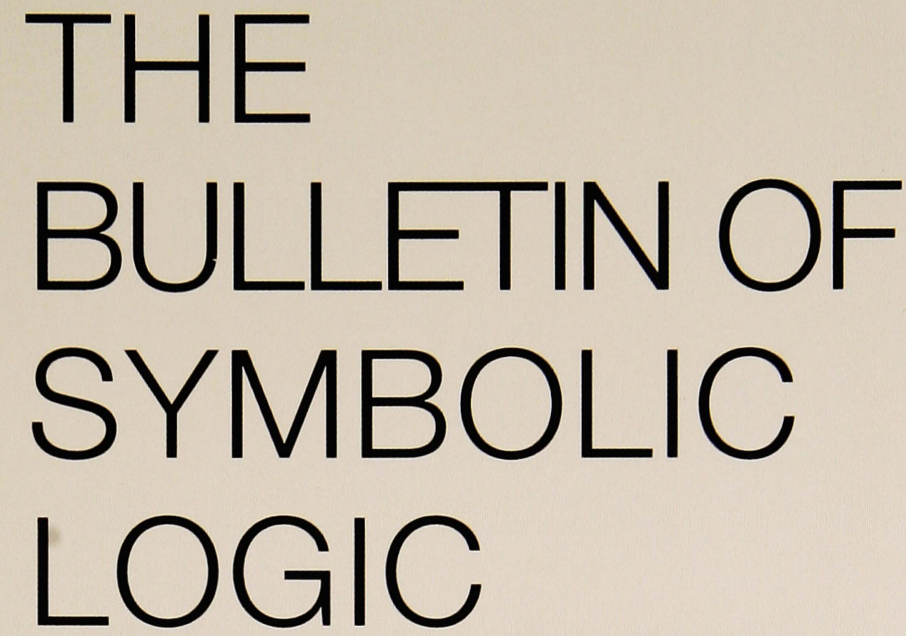

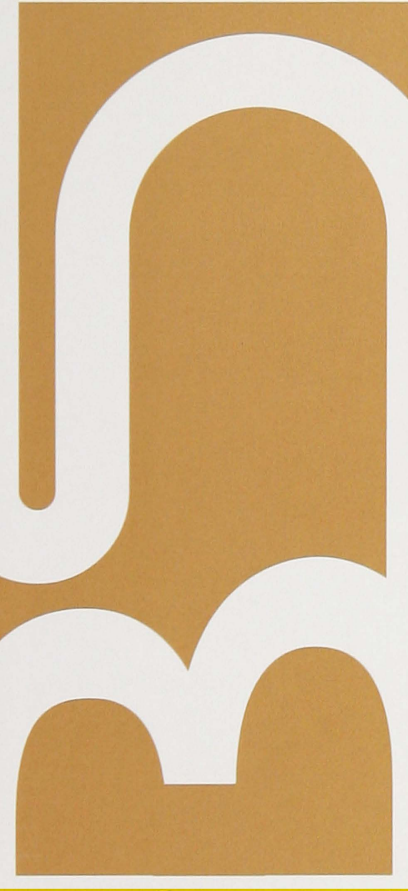

Anuj Dawar

Marcelo Fiore

Noam Greenberg

\section{Edited by}

John Baldwin, Managing Editor

Ilijas Farah

Michael Rathjen

Volker Halbach

Erich Reck

André Nies

Katrin Tent

Martin Otto

\section{Reviews Editors}

Steve Awodey, Managing Editor for Reviews

John Baldwin

Hannes Leitgeb

John Burgess

Ernest Schimmerling

Mark Colyvan

Carsten Schürmann

Anuj Dawar

Marcelo Fiore

Kai Wehmeier

Matthias Wille

\title{
Noam Greenberg
}

Kai Wehmeier

Matthias Wille

VOLUME 16 • NUMBER 4 • DECEMBER 2010 •ISSN 1079-8986 


\title{
TABLE OF CONTENTS
}

\begin{abstract}
ARTICLES
Well (and better) quasi-ordered transition systems, by Parosh AzIz AbDulla ...... Von Neumann, Gödel and complexity theory, by AlaSDAIR URQUHART $\ldots \ldots \ldots \ldots$.

\section{REVIEWS}

D. Hyde, Vagueness, logic and ontology. Reviewed by Nicholas J. J. Smith..........

N. J. J. Smith, Vagueness and degrees of truth. Reviewed by Dominic Hyde..........

W. Kienzler Begriff und Gegenstand. Reviewed by Matthias Wille................

A. Bobenrieth M., The origins of the use of the argument of trivialization in the twentieth century. Reviewed by Matthias Wille.........................
\end{abstract}

Officers and Committees of the Association for Symbolic Logic ................

Members of the Association ........................................... 545

Notices 600

The Bulletin of SymBolic Logic (ISSN print: 1079-8986, ISSN online: 1943-5894) is published quarterly, in the months of March, June, September, and December, by the Association for Symbolic Logic, Inc., 124 Raymond Avenue, Poughkeepsie, NY 12604-0001, USA. Periodicals postage is paid at Poughkeepsie NY and at additional mailing offices. The Bulletin is distributed with The Journal of Symbolic Logic. The 2010 annual subscription price for the two journals, in either print or electronic form, is US\$590; visit http://www . aslonline .org/Journals-subscription.html for more information. Postmaster: Send address changes to The Bulletin of Symbolic Logic, c/o American Mathematical Society, 201 Charles Street, Providence, RI 02904-2294, USA. Business correspondence should be sent to the Secretary-Treasurer of the Association, Charles Steinhorn (address on inside back cover).

The Bulletin, the Journal, and the Review of Symbolic Logic are the official organs of the Association for Symbolic Logic, an international organization for furthering research in all aspects of symbolic logic. The BULLETIN encourages submission of Articles and Communications in all areas of logic, including mathematical or philosophical logic, logic in computer science or linguistics, the history or philosophy of logic, and applications of logic to other fields. The BULLETIN also publishes reviews of publications in logic.

Articles should be of broad interest and accessible to a wide audience of logicians. They may be purely expository, survey, or historical articles, or they may contain, in addition, new ideas or results or new approaches to old ones.

Communications should be announcements of important new results and ideas in any aspect of logic; they may be short papers in their final form or preliminary announcements (extended abstracts, position papers) of longer, full papers that will be published elsewhere. In any case, they should include, in addition to a description of the new results or ideas, enough history, background, and explanation to make the significance of the work apparent to a wide audience. Communications will be quickly refereed and published within six months of the submission of final versions. 


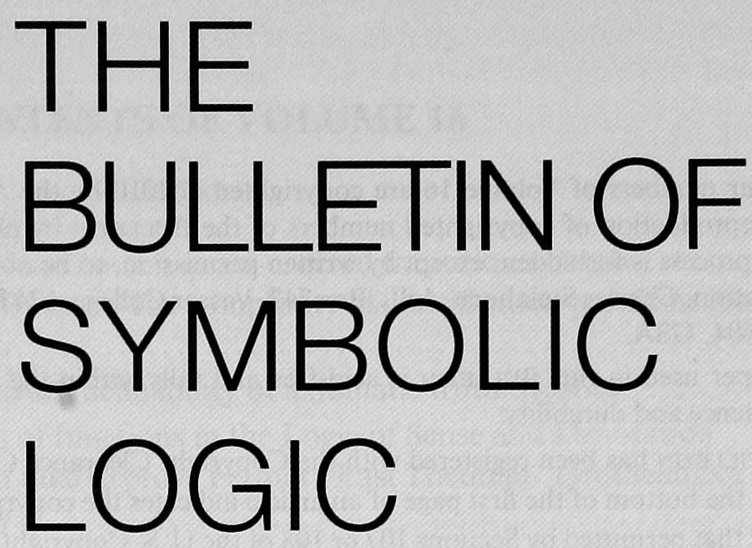

\section{Edited by}

John Baldwin, Managing Editor

Ilijas Farah

Michael Rathjen

Volker Halbach

Erich Reck

André Nies

Katrin Tent

Martin Otto

Reviews Editors

Steve Awodey, Managing Editor for Reviews

John Baldwin

Hannes Leitgeb

John Burgess

Ernest Schimmerling

Mark Colyvan

Carsten Schürmann

Anuj Dawar

Kai Wehmeier

Marcelo Fiore

Matthias Wille

Noam Greenberg

VOLUME $16 \cdot 2010$ 
The four numbers of Volume 16 are copyrighted (C)2010 by the Association for Symbolic Logic, Inc. Reproduction of copyrighted numbers of the BULLETIN by photostat, photoprint, microfilm, or like process is forbidden, except by written permission, to be obtained from the Secretary of the Association, Charles Steinhorn, ASL, Box 742, Vassar College, 124 Raymond Avenue, Poughkeepsie, NY 12604, USA.

The paper used in this BULLETIN is acid-free and falls within the guidelines established to ensure permanence and durability.

This Bulletin has been registered with the Copyright Clearance Center, Inc. The appearance of a code at the bottom of the first page of an article indicates the copyright owner's consent for copying beyond that permitted by Sections 107 or 108 of the U. S. Copyright Law, provided that the per-copy fee stated in the code is paid directly to Copyright Clearance Center, Inc., 222 Rosewood Drive, Danvers, MA 01923, USA. This consent does not extend to copying for general distribution, for advertising or promotion purposes, for creating new collective works, or for resale. Specific written permission for such copying must be obtained from the Association. 


\title{
CONTENTS OF VOLUME 16
}

\author{
ARTICLES
}

Abdulla, Parosh Aziz. Well (and better) quasi-ordered transition systems ....... COSKEY, SAMUEL and KosSAK, Roman. The complexity of classification problems for models of arithmetic

Fujimoto, Kentaro. Relative truth definability of axiomatic truth theories 345

Klement, Kevin C. The senses of functions in the Logic of Sense and Denotation 305 McLarty, Colin. What does it take to prove Fermat's Last Theorem? Grothendieck

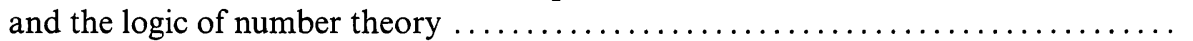
Medvedev, Alice and Takloo-Bighash, Ramin. An invitation to model-theoretic

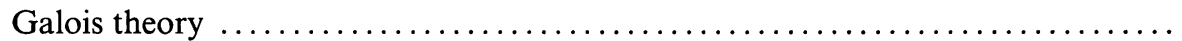

MoschovaKis, YianNIS N. Kleene's amazing Second Recursion Theorem ......... RaGHAVAN, Dilip. Almost disjoint families and diagonalizations of length continuum SHORE, RICHARD A. Reverse mathematics: the playground of logic $\ldots \ldots \ldots \ldots \ldots$. UrQuHART, AlasDAIR. Von Neumann, Gödel and complexity theory

\section{COMMUNICATIONS}

Corazza, Paul. The Axiom of Infinity and transformations $j: V \rightarrow V \ldots \ldots \ldots$

REVIEWS

A. Nies, Computability and randomness. Reviewed by Anthony Morphett ......... L. Kreiser, Logik und Logiker in der DDR. Eine Wissenschaft im Aufbruch. Reviewed

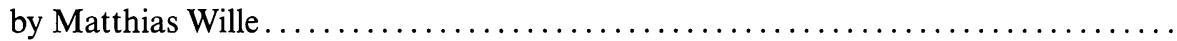
E. Menzler-Trott, Logic's lost genius: The life of Gerhard Gentzen. Reviewed by

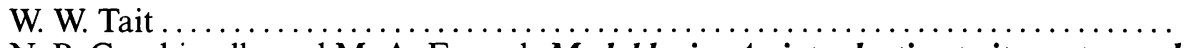
N. B. Cocchiarella and M. A. Freund, Modal logic. An introduction to its syntax and semantics. Reviewed by Heinrich Wansing ........................ K. Bimbó and J. M. Dunn Relational semantics of nonclassical logical calculi. Reviewed by Alasdair Urquhart . . . . . . . . . . . . . . . . . . . . . . . . . . .

J. Zapletal, Forcing idealized. Reviewed by Mirna Džamonja ................ J. Harrison, Handbook of practical logic and automated reasoning. Reviewed by

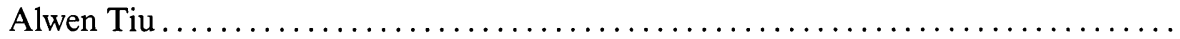
S. Givant and P. Halmos, Introduction to Boolean algebras. Reviewed by Natasha

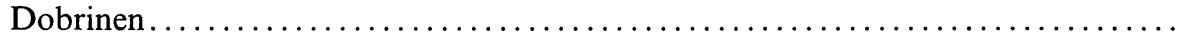
$\mathrm{R}$. Milner, The space and motion of communicating agents. Reviewed by Thomas Hildebrandt . .

Jc Beall, Spandrels of truth. Reviewed by Zach Weber 282

G. Gabriel. K. Huelser, and S. Schlotter, Zur Miete bei Frege-Rudolf Hirzel und die Rezeption der stoischen Logik und Semantik in Jena. Reviewed by Matthias Wille.. 
Two publications of G. Hjorth. Reviewed by Howard Becker

E. Grädel, P. Kolaitis, L. Libkin, M. Marx, J. Spencer, M. Vardi, Y. Venema, and

S. Weinstein Finite model theory and its applications. Reviewed by Stephan Kreutzer J. van Oosten, Realizability: an introduction to its categorical side. Reviewed by

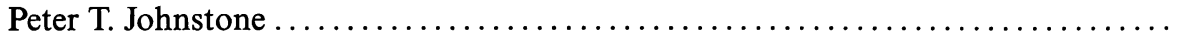
C. Benzmüller, C. Brown, J. Siekmann, and R. Statman (eds.), Reasoning in simple type theory. Reviewed by Florian Rabe.

J. Burgess, Philosophical logic. Reviewed by Lloyd Humberstone

M. Peterson, An introduction to decision theory. Reviewed by Steven Robertson ... G. Metcalfe, N. Olivetti and D. Gabbay, Proof theory for fuzzy logics. Reviewed by Bartosz Więckowski

A. Doxiadis, C. Papadimitriou, A. Papadatos, and A. di Donna, Logicomix. Re-

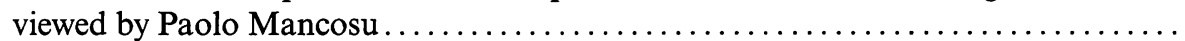

The search for diamonds. Reviewed by Assaf Rinot.................... Five papers on axiomatic theories of truth. Reviewed by Graham E. Leigh ....... M. Schirn, On translating Frege's Die Grundlagen der Arithmetik. Reviewed by Matthias Wille................................................

D. Hyde, Vagueness, logic and ontology. Reviewed by Nicholas J. J. Smith ........

N. J. J. Smith, Vagueness and degrees of truth. Reviewed by Dominic Hyde ........

W. Kienzler Begriff und Gegenstand. Reviewed by Matthias Wille .............. A. Bobenrieth M., The origins of the use of the argument of trivialization in the twentieth century. Reviewed by Matthias Wille.

\section{MeEtings of THE Association for Symbolic Logic}

2009 European Summer Meeting of the Association for Symbolic Logic, Logic Colloquium '09, Sofia, Bulgaria, July 31-August 5, 2009 ...................... 2009-2010 Winter Meeting of The Association for Symbolic Logic, Moscone Center West, San Francisco, CA, January $15-16,2010 \ldots \ldots \ldots \ldots \ldots \ldots \ldots \ldots \ldots \ldots \ldots$ 2010 Winter Meeting of the Association for Symbolic Logic, The Palmer House Hilton Hotel, Chicago, Illinois, February 18-20, 2010 .

\section{MEeTINGS SPONSORED BY THE ASSOCIATION FOR SyMbOLIC LOGIC}

16th Workshop on Logic, Language, Information and Computation (WoLLIC 2009), Tokyo, Japan, July 21-24, 2009

11 th Asian Logic Conference, National University of Singapore, Singapore, June 22-27, 2009

The 2009 Annual Conference of the Australasian Association for Logic. University of Melbourne, Australia, July 11-12, 2009 ............................

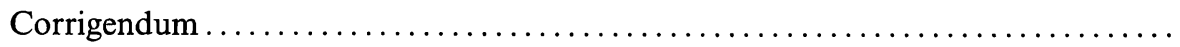

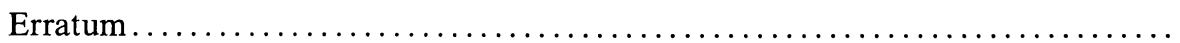

Notices

Officers and Committees of the Association for Symbolic Logic . . . . . . . . . . . . 539

Members of the Association ................................... 545 